\title{
Rolul și misiunea mănăstirii în teologia Sfântului Ioan Casian
}

\section{Alexandru-Lucian OJICĂ}

Abstract: St. John Cassian, the great disciple of Antiochian John Chrysostom, brought to the West not only an alexandrian christology, but also the tradition of Eastern monastic life. The foundation of two monasteries in Marseille (415), alongside his work, shows that the human vocation is assuming the road to Christ. The path to perfection is for every christian to follow their specific vocation, but the supported principles and lived by monks always been a landmark for all Christians. The parallelism between the monastic life and angels shows that monastery has a similar mission to angels, which is to convey the true faith confession.

Keywords: monastery, witnessing, Christology, tradition, St. John Cassian

\section{Preliminarii}

Viaţa monahală a jucat încă de la începuturile ei un rol important în definirea comunităţii creștine. Marii teologi, de regulă, au provenit 


\section{Alexandru-Lucian OJICĂ}

din mediul monahal unde au trăit experiența pustiului sau a vieții monahale de obște. În secolele IV-V ale erei noastre viața monahală în Occident a fost influențată de mai multe personalităţi: Fericitul Augustin, Fericitul Ieronim, Sfântul Martin - episcop de Tours şi îndeosebi Sfântul Ioan Casian (c. 360 - c. 435). În acest studiu miam propus să identific rolul pe care îl are mănăstirea în viața și opera Sfântului Ioan Casian. Monah din tinerețe, pelerin la locurile sfinte și trăitor în Egipt timp de aproape 20 ani, ajunge în capitala Imperiului Roman proaspăt fragmentat, unde este hirotonit diacon de Sfântul Ioan Gură de Aur. A mers la Roma în 404-405 cu o scrisoare către papa Inocențiu și rămâne pentru 10 ani. În 415 îl găsim în sudul Galiei, unde întemeiază două mănăstiri. Ultima parte a vieții sale, perioada din Marsilia este prolifică din punct de vedere literar, își scrie opera. Este un monah cu vocaţie de sinteză, nu este doar întemeietor, ci și organizator al vieţii monahale din Marsilia. Aduce Regulile Mari și Mici al Sfântului Vasile în Apus, fiind premergător Sfântului Benedict de Nursia pe care 1-a influențat foarte mult. Dacă ținem cont de forma, conținutul și modalitatea de organizare a monahismului creștin din secolele IV - V putem vedea o ,hartă” a climatului spiritual din acea perioadă - în 395 Imperiul a fost împărțit în mod oficial în două părți.

\section{Între Orient și Occident - viziunea despre monahism a Sfântului Ioan Casian}

Occidentul împrumută monahismul din Egipt. Sfântul Atanasie în exilul său la Treves trece și zăbovește prin Roma. Către 372, Rufin merge în Palestina cu patriciana Melania Romana. După ce a primit botezul Fericitul Ieronim merge și el în Orient și timp de trei ani trăiește în singurătatea deșertului Calcis. În Africa, Fericitul Augustin trage o linie de conduită generală. În Galia, creștinismul făcea progrese anevoioase până în vremea Sfântului Martin, episcop de 
Tours. Sfântul Ioan Casian aduce monahismul de factură răsăriteană în Apus. „În scrierile ascetice ale lui Casian (...) se remarcă o concepție foarte spiritualizată despre perfecțiunea creștină. După concepția apuseană, puritatea inimii premerge ascezei, pusă adesea pe primul plan în Orient"'.

Despre originea monahismului creștin s-a scris foarte mult, studiile arătând obârșia acestuia în modelul de viață dus de prima comunitate de creștini la care face referire Sfântul Evanghelist Luca (Faptele Apostolilor). Monahismul înseamnă în primul rând mai mult decât acea fuga mundi întâlnită și în mentalitatea antică ${ }^{2}$. Însăși concepția despre viață a creștinilor îi arăta pe aceștia străini după cum reiese din Epistola către Diognet: „Ei (creștinii) locuiesc fiecare în patria sa dar ca niște străini cu domiciliu... Tot pământul străin le este o patrie şi orice patrie le este un pământ străin"”. Viața duhovnicească a creștinilor purta cu ea o semnificație adâncă, „transfigurarea timpului” după cum afirma Olivier Clément: „Scopul vieții duhovnicești este de a trăi în istorie și de a «transfigura timpul», deoarece «eternitatea nu este ceva, ci Cineva, sau mai degrabă viaţa de iubire a Trei Persoane»" "4. Pentru Evagrie Ponticul, monahul e „,eel separat de toți și unit cu toți”’. Antinomia de a fi separat și unit în același timp arată specificitatea vieții monahale în viața comunității

\footnotetext{
${ }^{1}$ Mitropolit Efrem Enăcescu, Privire generală asupra monahismului creștin, Ediția a doua, Craiova, Editura Mitropolia Olteniei, 2007, p. 104.

2 În Noul Testament, în scrierile Sfântului Apostol Ioan și în epistolele pauline o teologie a fugii de lume unde se aprofundează noțiunea lumii acesteia care nu-L cunoaşte pe Hristos. Monahismul creștin aduce nu o fugă de lume înțeleasă în sens eudaimonist, ci dorește să realizeze viața veșnică (zoe) încă din timpul vieții (bios) trecătoare.

${ }^{3}$ Epistola către Diognet, V, 5, traducere, indici și note de pr. D. Fecioru în colecția „Părinți și Scriitori Bisericești”, vol. 1, București, Editura Institutului Biblic și de Misiune al Bisericii Ortodoxe Române, 1979, p. 340.

${ }^{4}$ O. Clément, Transfigurer le temps, Neuchâtel - Paris, 1959, p. 99 apud. Tomáš Špidlík, Spiritualitatea Răsăritului Creștin. I. Manual Sistematic, Ediția a II-a, traducere şi prezentare diac. Ioan I. Ică jr, Sibiu,Editura Deisis, 2005, p. 187.
}

${ }^{5}$ Ibidem, p. 204. 


\section{Alexandru-Lucian OJICĂ}

creștine. Căutarea mediului propice pentru împlinirea vocației proprii. Indiferent dacă trăiește în lume sau departe de ea, creștinul este în strânsă legătură cu membrii comunității din care provine. Tomáš Špidlík vede aici o liturghie și o structură dialogală: „Universul şi societatea umană au fost create ca un întreg, ca o mare «liturghie» celebrată în comun de toate ființele. (...) Dar această solidaritate a oamenilor între ei este una «dialogală»: chemarea deosebită a lui Dumnezeu constituie pentru fiecare legea ființei lui și a dezvoltării sale personale (Facerea 35, 10; Ieșire 31, 2; Isaia 45, 4) .

Monahismul prin ideea filosofică de communio naturae a dat teologi savanți. Părinții capadocieni, Sfântul Atanasie cel Mare - biograful Sfântul Antonie, Sfântul Ioan Gură de Aur, Fericitul Augustin, sunt exemple elocvente. Însă, mai presus de acest aspect care ține poate mai mult de latura lumească, monahismul a avut mereu în vizor aducerea aminte a desăvârşirii continue și a luptei împotriva influențelor demonice și a patimilor ${ }^{7}$. Modalitatea viețuirii, în mănăstire sau în singurătate -a ținut cont de porunca desăvârşirii exprimată de Mântuitorul Hristos în scrierile Noului Testament.

Din perspectiva logicii lui Hermes propusă de Constantin Noica, monahismul este o formă generală ce cuprinde în ea însăși toate modulaţiile individualului, în acest caz anahoretismul. Monahismul răsăritean se pliază pe această modalitate de interpretare deoarece anahoretul trebuia să cunoască viața de obște pentru ca apoi să se retragă în pustiu.

„Se întâmplă de fapt așa peste tot în lumea spiritului și a științelor spiritului, unde întregul este de fiecare dată în parte. O logică a lui Hermes ar avea sens cel puțin pentru științele spiritului: a «înțelege», cum voia Dilthey, înseamnă tocmai a vedea întregul în parte sau a interpreta

\footnotetext{
${ }^{6}$ Ibidem, p. 191.

${ }^{7}$ Nikolaos A. Matsoukas, Istoria filosofiei bizantine, Ediţia a 2-a, traducere de pr. prof. dr. Constantin Coman, Nicuşor Deciu, Bucureşti, Editura Bizantină, 2011, p. 115.
} 
întregul prin parte"s.

În acest sens, monahismul înțeles ca general asumă toate formele individualului cuprinse în anahoretism. Pentru Sfântul Ioan Casian viața monahală trebuie să fie organizată. Ieșirea dintr-o indiferență specifică vieții lumești pentru a intra și sta sub tensiunea unei ordini este primul pas spre desăvârșire. Cuvintele adresate de către Mântuitorul Hristos tânărului bogat sunt o bună dovadă în acest sens: „Dacă voiești să fii desăvârșit, du-te, vinde averea ta, dă-o săracilor, și vei avea comoară în cer; după aceea, vino și urmează-Mi." (Matei 19, 21). Monahismul este deci problemă de aplicație practică a vocației personale a fiecăruia.

Sfântul Ioan Casian este elocvent în acest sens:

„Aşadar prima renunțare este cea la lucrurile străine de noi, și de aceea ea singură nu este de ajuns pentru desăvârșire, dacă nu se ajunge la a doua, care constă în renunțarea la lucrurile noastre adevărate. Dobândind-o pe aceasta prin alungarea tuturor viciilor, ajungem și la renunțarea a treia, cea mai înaltă, prin care respingem cu inima și cu sufletul nu numai ceea ce se petrece în lume, sau ceea ce posedă omul în particular, ci chiar toate lucrurile socotite mărețe, privind, cum spune apostolul: «nu cele ce se văd, ci cele ce nu se văd; căci cele ce se văd sunt vremelnice, iar cele ce nu se văd veșnice»" .

Renunțarea la lume presupune progresul treptat către desăvârșire. Această creștere în viața cea nouă aduce o altă perspectivă, pentru că „monahul trebuie să trăiască «ca și cum ar trebui să moară în fiecare ziı"10. În acest sens, Sfântul Atanasie cel Mare sublinia rolul virtuţii

${ }^{8}$ Constantin Noica, Scrisori despre logica lui Hermes, București, Editura Cartea Românească, 1986, pp. 25-26.

${ }^{9}$ Sfântul Ioan Casian, Convorbiri duhovnicești, III, 10, 4, traducere de prof. Vasile Cojocaru și prof. David Popescu în colecția „Părinți și Scriitori Bisericești”, vol. 57, București, Editura Institutului Biblic și de Misiune al Bisericii Ortodoxe Române, 1990, p. 354.

${ }^{10}$ Tomáš Špidlík, op.cit., p. 160. 


\section{Alexandru-Lucian OJICĂ}

ca mod prin care Dumnezeu se oglindește în făptura mâinilor Sale:

„Deci nu e greu lucrul virtuții. Căci suntem în virtute dacă rămânem așa cum am fost făcuți. Iar dacă cugetăm cele rele, vom fi judecați ca răi. Dacă lucrul ar trebui căutat în afară de noi, ar fi cu adevărat greu. Dar dacă e în noi, să ne păzim de gânduri murdare și sufletul luat de la Domnul ca un dar spre păstrare, să-1 păzim pe seama Domnului"'11.

Viaţa monahală de obște este, în fapt, o comunitate, cea în care valorile creștine sunt cele după care întreaga viață este legiferată. Amintind de prima comunitate creștină, cea menționată de Sfântul Evanghelist Luca în Faptele Apostolilor, comunitatea este prima modalitate de organizare a vieții monahale și cea premergătoare ascetismului. A ajunge la trăirea în pustie, deci etapa următoare a vieții monahale, accesibile doar unora dintre monahi, presupune în primul rând o asumare integrală a ceea ce înseamnă viața de obște creștină și în al doilea rând capacitatea de a se detașa total de această lume urmărind unirea cu Dumnezeu. Tomáš Špidlík susţinea că ,pustnicii creștini nu iubesc singurătatea decât pentru a-L găsi pe Dumnezeu"12. De aceea Sfântul Vasile cel Mare insista pentru ca monahii să îmbrățișeze în primul rând viața de obște:

„Căci iată Domnul, din marea Lui iubire de oameni, nu Se mulțumește numai cu învățătura dată prin cuvinte, - ci, ca să ne dea nouă în mod precis și clar un exemplu de umilință în deplinătatea dragostei, Însuşi S-a încins și a spălat picioarele ucenicilor (Săi). Tu, însă, pe cine vei spăla? Pe cine vei servi? Față de cine vei fi, cel din urmă, dacă trăiești singur, (numai) cu tine? Cum se va împlini în locuința singuratică acea frumoasă și plăcută locuire împreună a fraților, pe care Duhul Sfânt o aseamănă cu

\footnotetext{
${ }^{11}$ Sfântul Atanasie cel Mare, Viața Cuviosului nostru părinte Antonie, XX, traducere din grecește, introducere și note de pr. prof. Dumitru Stăniloae, colecția „Părinți și Scriitori Bisericești”, vol 16, București, Editura Institutului Biblic și de Misiune al Bisericii Ortodoxe Române, 1988, pp. 205-206.
}

${ }^{12}$ Ibidem, p. 259. 
mirul ce-şi împrăștie miresmele de pe capul arhiereului?’’13.

Problema anahoretismului e simplă în gândirea răsăriteană, cea „de a ști până unde anume singurătatea exterioară e necesară sau utilă liniștii sale lăuntrice"'14. Sfântul dobrogean afirmă următoarele:

„Trei sunt în Egipt categoriile de monahi, din care două sunt foarte bune, iar al treilea este călduț și trebuie evitat pe toate căile. Prima categorie este a chinovnicilor, care stând toți la un loc în comunitate sunt conduși de înțelepciunea unui bătrân. (...) A doua este a anahoreților formată din acei călugări care au fost formați și desăvârșiţi în mănăstiri și în prezent au ales retragerea în singurătățile pustiului. (...) A treia este cea nevrednică de a fi imităm aceea a sarabaiților"15.

\section{Rolul mănăstirii în societate conform teologiei casiene}

Ce a produs comunitatea monahală a Bisericii? Cum a influențat societatea orientală și apuseană din secolele IV-V, prin specificul ei, modus vivendi monahismul? Iată cum sunt ele reflectate în scrierile Sfântului Ioan Casian.

În primul rând, Sfântul dobrogean susține că viața monahală este o formă de mărturisire a învățăturii hristice. Cei care au vocația de a-și dedica întreaga viață lui Hristos, inclusiv prin retragerea din lume, sunt mărturisitori ai învățăturii creștine. O paralelă interesantă găsim la Adalbert de Vogüé care spune că dorința de organizare şi continuitate va merge, la Casian, până la a grupa ultima sa lucrare, „De Incarnatione Domini contra Nestorius", cu scrierile sale monastice anterioare. Această operă dogmatică, va scrie el în Prefaţa pentru

\footnotetext{
${ }^{13}$ Sfântul Vasile cel Mare, Regulile Mari VII, 4, traducere, introducere, indici şi note de prof. Iorgu D. Ivan în „Părinți și Scriitori Bisericești”, vol. 18, București, Editura Institutului Biblic şi de Misiune al Bisericii Ortodoxe Române, 1989, p. 234.

${ }^{14}$ Tomáš Špidlík, op.cit., p. 258.

${ }^{15}$ Sfântul Ioan Casian, op.cit., XVIII, IV, 2, p. 628.
} 


\section{Alexandru-Lucian OJICĂ}

Leon, este ca un fel de culme, o intrare în Sfânta Sfinţilor după un sejur în partea de sanctuar accesibilă tuturor ${ }^{16}$.

Năzuința monahului trebuie să fie înălțarea minții la cele duhovnicești: „Aceasta trebuie să fie năzuința pustnicului, aceasta toată strădania. (...) Aceasta este, spun, scopul oricărei desăvârșiri, (...) până ce toată viața și bătaia inimii vor deveni o singură și neîntreruptă rugăciune" ${ }^{\prime 17}$.

Interpretând ideea de fugă, Sfinții Părinți dar și exegeții lor au văzut în aceasta o metanoia adică o întoarcere la credință. Deși a existat o separare de lume, monahii au rămas în legătură și au comunicat cu cei care-i căutau, au rămas în comuniune cu lumea. Dialogul cu intelectualitatea timpului dar și cu puterea politică mereu a existat, în Alexandria găsim o puternică şcoală teologică ce a știut să realizeze „o imagine unificată a teologiei și a paideiei grecești, unde deja nu subzistă vreo separare schizofrenică între cunoașterea lumească și cea teologică"18.

Sfântul Ioan Casian a pledat pentru o regulă universală dar graduală care să aibă în vedere vocația fiecăruia.

„Căci nu din partea cea mai mică, rezultând din părerile puținora, ci din aceea a multora, care cuprinde dacă se poate spune părerile tuturor, trebuie formulată o regulă universală. Dacă puțini, care depășesc putințele virtuții comune, obțin foarte rar rezultatele dorite, aceștia nu trebuie încadrați în normele generale, fiindcă sunt ceva pe deasupra condiției umane slabe și neputincioase, și nu sunt de dat ca exemplu, ci ca niște minunate excepții. (...) Țelul chinovnicului este de a-și ucide și răstigni toate dorințele sale, iar potrivit poruncii mântuitoare despre desăvârşirea evanghelică, de a nu cugeta nimic despre ziua de mâine"19.

\footnotetext{
${ }^{16}$ Adalbert de Vogüé, Histoire littéraire du mouvement monastique dans l'antiquité, Paris, Les Editions du Cerf, 2002, p. 443.

${ }^{17}$ Sfântul Ioan Casian, op.cit., IX, VII, 2-3, p. 480.

${ }^{18}$ Nikolaos A. Matsoukas, op.cit., p. 99.

${ }^{19}$ Sfântul Ioan Casian, op.cit., XXIII, p. 703.
} 
Așadar, viața comună este cea propusă de teologia casiană pentru că acolo se poate găsi ușor ajutor și îndrumare din partea părintelui duhovnicesc, comuniunea fiind cea mai bună soluție la problemele de natură materială și spirituală întâlnite în această lume. Viața de zi cu zi a monahilor presupune și munca dar una care în atmosfera specifică retragerii din lume să favorizeze rugăciunea, o rugăciune construită pe sentimentul de iubire ${ }^{20}$. Aceasta este caracterizată de Sfântul Ioan Casian în sensul ei de afecțiune ce se dăruiește numai câtorva persoane pentru că în sufletul lor se întâlnesc aceleași virtuți.

„Dragostea care, neurând pe nimeni, iubește mai mult pe unii prin dreptul meritelor și care, deși iubește pe toți în general, alege totuși din ei pe cei pe care trebuie să-i iubească cu deosebită afecțiune, între cei ce sunt în cea mai înaltă și deosebită atenție păstrând pe cineva, care se înalță mai mult decât ceilalți în afecțiunea sa" ${ }^{\prime 21}$.

Cei 18 ani petrecuți în Egipt de Sfântul Ioan Casian, alături de prietenul său Gherman, unde au vizitat diverse mănăstiri și monahi îmbunătățiți s-au reflectat în modul cum a organizat viaţa monahală în Marsilia în cele două mănăstiri. Ideea Sfântului Benedict de Nursia, cel care a implementat cel mai bine ideile Sfântului Ioan Casian, a fost să formeze o comunitate de monahi care să trăiască în viața de obște, sub o singură regulă, în mănăstirea de metanie, constituind o familie al cărei părinte este abatele. Contribuția cea mai de seamă a Sfântului Benedict în dezvoltarea vieții monastice a fost deci introducerea votului stabilității, care favorizează spiritul de familie în comunitățile monahale ${ }^{22}$.

Legătura monahului cu mănăstirea sa de metanie au schimbat și cadrul legislativ al funcționării vieții de obște creștine. „Între orele consacrate rugăciunii, lucrul manual și intelectual își avea locul

\footnotetext{
${ }^{20}$ Tomáš Špidlík, op.cit., p. 215

${ }^{21}$ Sfântul Ioan Casian, op.cit., p. 583.

${ }^{22}$ Mitropolit Efrem Enăcescu, op.cit., p. 107.
} 


\section{Alexandru-Lucian OJICĂ}

hotărât, îngrijirea completă a monahului de către mănăstire făcea de asemenea posibilă aplicarea cu strictețe a votului sărăciei de bună voie, căci deviza era „Toate tuturor să fie de obște”23. Dar cei care îi pun în contrast pe sfinții Benedict de Nursia și Ioan Casian nu au realizat întotdeauna unul a fost un teolog ascetic (Sfântul Ioan Casian), celălalt un administrator (Sfântul Benedict de Nursia); unul a căutat să-și expună spiritualitatea, celălalt a construit un cadru pentru spiritualitatea existentă. De vreme ce regula Sfântului Benedict ar fi de neînțeles fără mentalitatea casianică și baziliană din spatele ei, nu putem afirma că doctrina predicată de la Marsilia vizează un ideal eronat iar cea de la abaţia din Cassino reprezintă gândirea monahală medievală la cel mai înalt nivel. Criticii Sfântului Ioan Casian trebuie să devină critici ai Sfântului Benedict, ce a încorporat în mare parte gândul și spiritualitatea misionarului Ioan Casian² ${ }^{24}$. Mai degrabă, contemplația a fost pentru Ioan Casian însumarea virtuții creștine întruchipată şi exprimată în totalitatea ei: este dragostea de Dumnezeu, ce unește pe creștin cu Dumnezeu și cu semenii săi ${ }^{25}$.

\section{Concluzii}

Monahismul cu specificul tradiţiei răsăritene este îndeosebi un modus vivendi. Sfântul Ioan Casian a adus în Occident această percepție asupra realităţii așa cum a întâlnit-o el în Orient. Mănăstirea este locul cel mai sigur unde monahii pot dobândi mântuirea pentru că în mijlocul comunităţii poți crește din punct de vedere spiritual. Partea practică exprimată prin muncă este mereu alături de partea contemplativă. Mănăstirea a adus lumii conform gândirii casiene un model de viețuire în

\footnotetext{
${ }^{23}$ Ibidem, p. 105.

${ }^{24}$ Owen Chadwick, John Cassian - a study in primitive monasticism, Cambridge at the University Press, 1950, p. 174.

${ }^{25}$ A. M. C. Casiday, Tradition and theology in St John Cassian, Oxford University Press, 2006, pp. 64-65.
} 
care este exprimată năzuința după viața veșnică chiar și prin muncă. De aici a apărut firesc dictonul ora et labora exprimat pentru prima dată de Sfântul Benedict de Nursia.

$\mathrm{Cu}$ toate acestea, Sfântul Ioan Casian nu opune partea practică și partea contemplativă. Învăţătura lui afirmă cu tărie imperativul milostivirii. Chiar anahoreții cei mai îmbunătățiți, trebuie să răspundă mai multor persoane care vor vedea și vor fi îndrumate de acea dragoste susamintită: ,să nu fie vizitat de alții este indicație de o rigoare nerezonabilă și nechibzuită, sau chiar de cea mai mare răceală'’26.

Pentru Casian, adevărații asceți se găseau în deșert, departe de orașe, fie în chilii anahoretice sau chiar mai bine în coenobia monastică. Aici au trăit cei care cu răbdare și persistență au luptat cu patimile interioare și cu ispitele demonice din afară. Ei au înaintat spre desăvârșire sub supravegherea atentă a părinților duhovnicești, cei care au dobândit o vastă experiență după lupte lungi și continue cu diferite ispite ${ }^{27}$. Trăirea sub altă logică dar una care trimite direct la viaţa veșnică în Împărăția lui Hristos este ce a adus viaţa monahală lumii. Rolul ei este unul aşadar educator și misionar în același timp deoarece valorile propuse nu sunt perene, ci vizează schimbarea interioară a fiecărei persoane.

\section{Bibliografie}

1. $\quad * * *$, Epistola către Diognet, $\mathrm{V}, 5$, traducere, indici și note de pr. D. Fecioru în colecția „Părinți și Scriitori Bisericești”, vol. 1, București, Editura Institutului Biblic și de Misiune al Bisericii Ortodoxe Române, 1979.

2. Casiday, A. M. C., Tradition and theology in St John Cassian, Oxford University Press, 2006.

\footnotetext{
${ }^{26}$ Columba Steward, Cassian the monk (Oxford Studies in Historical Theology), New York and Oxford: Oxford University Press, 1998, p. 54.

${ }^{27}$ Cristian Gaspar, Cassian's syrian Monastic Contemporaries in Jean Cassien entre l'Orient et l'Occident, éd. Cristian Badilita et Attila Jakab, Paris Beauchesne Éditeur; Iaşi, Polirom, 2003, p. 17.
} 


\section{Alexandru-Lucian OJICĂ}

3. Chadwick, Owen, John Cassian - a study in primitive monasticism, Cambridge at the University Press, 1950.

4. Enăcescu, Efrem, Privire generală asupra monahismului creștin, Craiova, Ediția a doua, Editura Mitropolia Olteniei, 2007.

5. Gaspar, Cristian, Cassian's syrian Monastic Contemporaries in Jean Cassien entre l'Orient et l'Occident, éd. Cristian Badilita et Attila Jakab, Paris Beauchesne Éditeur; Iași, Polirom, 2003.

6. Matsoukas, Nikolaos A., Istoria filosofiei bizantine, Ediţia a 2-a, traducere de pr. prof. dr. Constantin Coman, Nicuşor Deciu, București, Editura Bizantină, 2011.

7. Noica, Constantin, Scrisori despre logica lui Hermes, București, Editura Cartea Românească, 1986.

8. Špidlík, Tomáš, Spiritualitatea Răsăritului Creștin. I. Manual Sistematic, Ediția a II-a, traducere și prezentare diac. Ioan I. Ică jr, Sibiu, Editura Deisis, 2005.

9. Sfântul Atanasie cel Mare, Viața Cuviosului nostru părinte Antonie, traducere din grecește, introducere și note de pr. prof. Dumitru Stăniloae, colecția „Părinți și Scriitori Bisericești”, vol. 16, București, Editura Institutului Biblic și de Misiune al Bisericii Ortodoxe Române, 1988.

10. Sfântul Ioan Casian, Așezămintele mănăstirești, traducere de prof. Vasile Cojocaru și prof. David Popescu în colecția „Părinți și Scriitori Bisericești”, vol. 57, București, Editura Institutului Biblic și de Misiune al Bisericii Ortodoxe Române, 1990.

11. Sfântul Ioan Casian, Convorbiri duhovnicești, traducere de prof. Vasile Cojocaru şi prof. David Popescu în colecția „Părinţi și Scriitori Bisericești”, vol. 57, București, Editura Institutului Biblic și de Misiune al Bisericii Ortodoxe Române, 1990.

12. Sfântul Vasile cel Mare, Regulile Mari, traducere, introducere, indici și note de prof. Iorgu D. Ivan în „Părinţi și Scriitori Bisericești”, vol. 18, București, Editura Institutului Biblic și de Misiune al Bisericii Ortodoxe Române, 1989.

13. Steward, Columba, Cassian the monk (Oxford Studies in Historical Theology), New York and Oxford: Oxford University Press, 1998.

14. Vogüé, Adalbert de, Histoire littéraire du mouvement monastique dans l'antiquité, Paris, Les Editions du Cerf, 2002. 